\title{
OPEN Crosses with spelt improve tolerance of South Asian spring wheat to spot blotch, terminal heat stress, and their combination
}

\author{
Ajeet Kumar Pandey ${ }^{1}$, Vinod Kumar Mishra ${ }^{1 凶}$, Ramesh Chand ${ }^{2}$, Sudhir Navathe ${ }^{3}$, \\ Neeraj Budhlakoti ${ }^{4}$, Jayasudha Srinivasa ${ }^{1}$, Sandeep Sharma ${ }^{1}$ \& Arun Kumar Joshi ${ }^{5,6}$
}

Spot blotch and terminal heat are two of the most important stresses for wheat in South Asia. A study was initiated to explore the use of spelt (Triticum spelta) to improve tolerance to these stresses in spring wheat (T. aestivum). We assessed 185 recombinant inbred lines (RILs) from the cross $T$. spelta $(\mathrm{H}+26) \times T$. aestivum (cv. HUW234), under the individual stresses and their combination. $\mathrm{H}+26$ showed better tolerance to the single stresses and also their combination; grain yield in RILs was reduced by $21.9 \%, 27.7 \%$ and $39.0 \%$ under spot blotch, terminal heat and their combined effect, respectively. However, phenological and plant architectural traits were not affected by spot blotch itself. Multivariate analysis demonstrated a strong negative correlation between spikelet sterility and grain yield under spot blotch, terminal heat and their combination. However, four recombinant lines demonstrated high performance under both stresses and also under their combined stress. The four lines were significantly superior in grain yield and showed significantly lower AUDPC than the better parent. This study demonstrates the potential of spelt wheat in enhancing tolerance to spot blotch and terminal heat stresses. It also provides comprehensive evidence about the expression of yield and phenological traits under these stresses.

Wheat is a staple food crop that contributes about $20 \%$ of the total calories and protein in 89 countries across the world (https://wheat.org/wheat-in-the-world) and is critical for 2.5 billion people who live on less than US $\$ 2 /$ day, of whom most are women and children ${ }^{1}$. It is extremely important for the food and nutritional security of the thickly populated region of South Asia, home to more than 1.8 billion people. The climate of the Eastern Gangetic Plains (EGP) of South Asia is characterized by high temperature and high humidity ${ }^{2}$. These, in turn, make the wheat crop particularly vulnerable to the two stresses-biotic (spot blotch) and abiotic (terminal heat). Spot blotch caused by fungus Bipolaris sorokiniana can assume epidemic proportions in the EGP region, including India, Nepal and Bangladesh. It has been reported to spread into cooler traditional rice-wheat production areas as well ${ }^{3,4}$. At least $17.5 \%$ yield losses has been reported in wheat due to leaf blight in the Indian subcontinent ${ }^{5}$. It is estimated that 10 Mha of wheat are affected by spot blotch in South Asia, of which 9 Mha are within India alone ${ }^{6}$. Most of it falls under the rice-wheat cropping system which often provides an environment favourable for the survival and multiplication of foliar blight pathogens, particularly due to late sowing of wheat after the preceding paddy crop ${ }^{6}$. Of the $220 \mathrm{Mha}$ put to wheat globally, $25 \mathrm{Mha}$ is affected by spot blotch ${ }^{7}$. Hence, this disease has become a major wheat production constraint not only in the EGP but also in warmer regions worldwide ${ }^{6,8}$ including North and Latin America ${ }^{9}$, Brazil $^{10}$, and to some extent in parts of Europe.

Terminal heat, another major stress in wheat, is estimated to affect approximately 13.5 Mha of the wheatgrowing area $\left(\sim 40 \%\right.$ of the total irrigated area) in India alone ${ }^{11}$. Temperatures above $35^{\circ} \mathrm{C}$ before March 30 , which were uncommon in the previous century, are now a frequent occurrence in India's EGP where spot blotch is already a dominant pathogen ${ }^{2}$. Wheat is very sensitive to heat stress especially at reproductive and grain filling stages ${ }^{12}$. Rane et al. ${ }^{13}$ have shown that temperatures $>30^{\circ} \mathrm{C}$ at pre-and-post anthesis minimizes the rate of grain

\footnotetext{
${ }^{1}$ Department of Genetics and Plant Breeding, Institute of Agricultural Sciences, BHU, Varanasi 221005, India. '2Department of Mycology and Plant Pathology, Institute of Agricultural Sciences, BHU, Varanasi 221005, India. ${ }^{3}$ Genetics and Plant Breeding Group, Agharkar Research Institute, Pune 411004, India. ${ }^{4}$ ICAR- Indian Agricultural Statistics Research Institute, New Delhi 110012, India. ${ }^{5}$ International Maize and Wheat Improvement Centre (CIMMYT), DPS Marg, New Delhi 110012, India. ${ }^{6}$ Borlaug Institute for South Asia (BISA), DPS Marg, New Delhi 110012, India. ${ }^{\otimes}$ email: vkmishra.gpb@bhu.ac.in
} 


\begin{tabular}{|c|c|c|c|c|c|c|c|c|c|c|c|c|c|}
\hline $\begin{array}{l}\text { Source of } \\
\text { Variation }\end{array}$ & d.f & AUDPC & BM & DH & GI & GPS & PH & PL & PY & SL & SPS & SS & TKW \\
\hline Genotype & 186 & $101,354.0^{*}$ & $2639.28^{\star}$ & $259.25^{*}$ & $16.27^{*}$ & $222.33^{*}$ & $377.52^{\star}$ & $139.21^{\star}$ & $890.84^{*}$ & $6.83^{*}$ & $132.62^{*}$ & $419.61^{*}$ & $179.77^{*}$ \\
\hline Treatment & 3 & $98,060,744.6^{*}$ & $299,620.45^{*}$ & $43,912.48^{*}$ & $14.27^{*}$ & $35,078.66^{*}$ & $35,518.55^{*}$ & $7129.93^{*}$ & $166,655.64^{*}$ & $147.08^{*}$ & $9155.14^{*}$ & $45,863.23^{*}$ & $27,641.68^{\star}$ \\
\hline Year & 2 & $1,072,244.4^{\star}$ & $242,009.17^{*}$ & $801.22^{\star}$ & 15.6 & $6346.42^{*}$ & $6037.95^{\star}$ & $533.71^{*}$ & $23,499.18^{*}$ & $225.46^{*}$ & $529.02^{*}$ & $17,356.01^{*}$ & $5050.54^{\star}$ \\
\hline Replication & 1 & 5734.3 & 1737.94 & 2.5 & 19.11 & 161.85 & $374.99^{*}$ & 41.6 & 51.53 & 0.6 & $536.43^{*}$ & 0.17 & 0.01 \\
\hline $\begin{array}{l}\text { Geno- } \\
\text { type } \times \text { Treat- } \\
\text { ment }\end{array}$ & 558 & $27,151.5^{*}$ & $529.47^{*}$ & $8.75^{*}$ & $2.95^{*}$ & $38.92^{*}$ & $62.16^{\star}$ & $24.64^{*}$ & $113.20^{*}$ & $2.13^{*}$ & $21.44^{*}$ & $186.97^{\star}$ & $28.07^{*}$ \\
\hline $\begin{array}{l}\text { Geno- } \\
\text { type } \times \text { Year }\end{array}$ & 372 & $16,488.1^{*}$ & $575.53^{*}$ & $8.01^{*}$ & 2.17 & $68.40^{*}$ & $85.92^{\star}$ & $33.51^{\star}$ & $138.82^{*}$ & $2.70^{*}$ & $17.88^{*}$ & $256.82^{*}$ & $39.65^{*}$ \\
\hline $\begin{array}{l}\text { Treat- } \\
\text { ment } \times \text { Year }\end{array}$ & 6 & $213,147 . *$ & $44,147.28^{*}$ & $2362.30^{*}$ & $34.25^{*}$ & $554.65^{*}$ & $20,892.51^{\star}$ & $2489.83^{*}$ & $6123.84^{*}$ & $55.42^{*}$ & $341.99^{*}$ & $1676.28^{*}$ & $553.38^{*}$ \\
\hline $\begin{array}{l}\text { Geno- } \\
\text { type } \times \text { Treat- } \\
\text { ment } \times \text { Year }\end{array}$ & 1116 & $8973.3^{*}$ & $390.72^{*}$ & $5.14^{*}$ & 2.08 & $29.93^{*}$ & $76.57^{\star}$ & $25.12^{*}$ & $92.28^{*}$ & $2.18^{*}$ & $10.77^{*}$ & $185.44^{*}$ & $20.05^{*}$ \\
\hline Error & 2242 & 3755.4 & 154.6 & 2.18 & 2.06 & 12.93 & 13.5 & 7.4 & 23.91 & 0.71 & 8.35 & 135.21 & 8.91 \\
\hline
\end{tabular}

Table 1. Analysis of variance of 11 traits studied under different treatments and environments. ${ }^{*}$ Significant at $P<0.01$. AUDPC, Area under disease progress curve; BM, 50 Tiller biomass; DH, Days to heading; GI, Glaucousness Index; GPS, Grains per spike; PH, Plant height; PL, Peduncle length; PY, Plot yield; SL, Spike length; SPS, Spikelets per spike; SS, Spikelet sterility; TKW, Thousand kernel weight.

filling and thus reduces wheat production. Wheat is expected to experience one of the most severe crop yield declines from global warming, particularly related to night time temperatures in low-latitude countries ${ }^{14-16}$. Indeed, the Inter-governmental Panel on Climate Change ${ }^{17}$ has predicted that climate change alone may result in a $20 \%$ reduction in South Asia's annual wheat production by 2030, amounting to US $\$ 7.7$ billion in crop losses per year. The future is bleaker: by 2050 , climate change may shrink wheat production further, by $30-40 \%{ }^{17}$.

A significant proportion of wheat in South Asia experiences combined spot blotch and terminal heat stresses ${ }^{11}$. This combination is recognized as a major challenge for wheat production in the $\mathrm{EGP}^{2,11}$. As the most detrimental impacts of both spot blotch and terminal heat stresses coincide with the stage when wheat starts the transition from vegetative growth to grain formation, yields are severely diminished. Attributing to the fact that south Asian wheat growing season is characterised by high humidity and high temperature, it is favourable for spot blotch particularly during flowering and grain filling stage $e^{2,18}$. Heat stress and spot blotch have been found to be positively associated ${ }^{19}$. Moderate to warm temperature range $\left(18\right.$ to $\left.32{ }^{\circ} \mathrm{C}\right)$ generally favours the growth of spot blotch pathogen Bipolaris sorokiniana. Winter rainfall in south Asia is known to worsen the situation. Even in the absence of rainfall, high relative humidity arising from soil residual moisture along with foggy days (which are quite common in NEPZ) cause prolonged wetness on leaf blades and sheath that can last until late January to first fortnight of February, creating ideal conditions for the establishment and multiplication of pathogen ${ }^{20}$. Thus, spot blotch in combination with higher temperature at reproductive phase is even more detrimental causing increased yield losses mainly due to reduction in grain number and grain weight ${ }^{21}$. Reports on independent segregation of spot blotch and earliness hints at possibilities of developing early maturing wheat lines coupled with appreciable resistance to spot blotch so as to obtain high yield by employing escape mechanism against exposure to terminal heat stress ${ }^{2}$. Common tolerance mechanisms have sparsely been reported to combat both spot blotch and terminal heat stress.

Hence, it is imperative to manage both stresses simultaneously in the wheat breeding programs of this region. Most of earlier studies have focused on separate investigations of spot blotch or terminal heat stress in wheat, often in T. aestivum $\times$ T. aestivum crosses. Although a few studies have attempted to investigate the effects of the simultaneous stresses ${ }^{11,19}$, they do not provide comprehensive insights under controlled individual and combined stress conditions.

Spelt wheats show promise against abiotic stresses ${ }^{22}$ and generally they are more robust during the early stages of crop growth. The significance of wide hybridization has been highlighted in breeding for heat stress using T. spelta and other hexaploid germplasm accessions ${ }^{23}$. This indicates that T. spelta may be used as a potential source to improve the performance of wheat lines against various stresses. This appears quite logical since over a long period of domestication and breeding, wheat has lost a significant proportion of its genetic diversity and is considered to have a narrow genetic base ${ }^{23}$. The present study was performed to (i) identify elite lines derived from $T$. spelta $(\mathrm{H}+26) \times T$. aestivum (cv. HUW234) having appreciable tolerance to spot blotch, terminal heat stress and their combination and (ii) to study the response of this population under spot blotch, terminal heat and their combination.

\section{Results}

Impact of spot blotch, terminal heat stress and their combination on the parents $T$. spelta and $T$. aestivum and the population derived from them. Analysis of variance for the traits studied is presented in Table 1. ANOVA showed pronounced variation among the genotypes for all the studied traits. Furthermore, the interactions between the components of genotype $\times$ treatment $(\mathrm{G} \times \mathrm{E})$ and genotype $\times$ treatment $\times$ year were observed to be significant. This indicates that genotypes had different responses for the treat- 


\begin{tabular}{|c|c|c|c|c|c|}
\hline \multirow[b]{3}{*}{ Trait } & \multirow[b]{3}{*}{ Parent genotype } & \multicolumn{4}{|l|}{ Treatments and environments } \\
\hline & & Control & Spot blotch & Terminal heat stress & $\begin{array}{l}\text { Spot blotch and terminal heat } \\
\text { stress }\end{array}$ \\
\hline & & $\begin{array}{l}\text { (Timely sown protected with } \\
\text { fungicide) }\end{array}$ & $\begin{array}{l}\text { (Timely sown inoculated with } \\
\text { pathogen) }\end{array}$ & $\begin{array}{l}\text { (Late sown protected with } \\
\text { fungicide) }\end{array}$ & $\begin{array}{l}\text { (Late sown and inoculated with } \\
\text { pathogen) }\end{array}$ \\
\hline \multirow{2}{*}{ AUDPC } & $\mathrm{H}+26$ & $117.87 \pm 12.22$ & $226.19 \pm 7.61(91.89 \%)$ & $190.56 \pm 7.48(61.67 \%)$ & $381.64 \pm 6.97(223.78 \%)$ \\
\hline & HUW 234 & $275.87 \pm 12.26$ & $847.12 \pm \mathbf{5 0 . 2 1}(\mathbf{2 0 7 . 0 7 \% )}$ & $326.09 \pm 27.34(\mathbf{1 8 . 2 0} \%)$ & $1106.78 \pm 13.33(301.20 \%)$ \\
\hline \multirow{2}{*}{$\mathrm{BM}(\mathrm{g})$} & $\mathrm{H}+26$ & $196.67 \pm 14.14$ & $190 \pm 4.71(-3.31 \%)$ & $176.67 \pm 4.71(-\mathbf{1 0 . 1 7 \% )}$ & $168.33 \pm 2.36(-14.41 \%)$ \\
\hline & HUW 234 & $158.33 \pm 2.36$ & $141.67 \pm 11.79(-10.52 \%)$ & $116.67 \pm 4.71(-26.31 \%)$ & $116.67 \pm 4.71(-26.31 \%)$ \\
\hline \multirow{2}{*}{ DH (d) } & $\mathrm{H}+26$ & $111 \pm 0$ & $110.33 \pm 1.41(-\mathbf{0 . 6 0} \%)$ & $105.33 \pm 1.41(-\mathbf{5 . 1 2} \%)$ & $102.83 \pm 0.24(-7.36 \%)$ \\
\hline & HUW 234 & $71.50 \pm 0.71$ & $73 \pm 1.41(2.10 \%)$ & $62.50 \pm 0.24(-12.59 \%)$ & $61 \pm 0.47(-\mathbf{1 4 . 6 8} \%)$ \\
\hline \multirow{2}{*}{ GI } & $\mathrm{H}+26$ & $1.92 \pm 0.35$ & $1 \pm 00(-47.92 \%)$ & $1.50 \pm 00(-21.88 \%)$ & $1.50 \pm 00(-21.88 \%)$ \\
\hline & HUW 234 & $4.33 \pm 0.24$ & $2 \pm 00(-\mathbf{5 3 . 8 1} \%)$ & $4.25 \pm 0.35(-\mathbf{1 . 8 5} \%)$ & $2.75 \pm 0.35(-36.50 \%)$ \\
\hline \multirow{2}{*}{ GPS } & $\mathrm{H}+26$ & $41.66 \pm 0.32$ & $41.43 \pm 1.03(-\mathbf{0 . 5 5 \%})$ & $37.58 \pm 0.75(-9.79 \%)$ & $36.43 \pm 1.46(-\mathbf{1 2 . 5 5 \% )}$ \\
\hline & HUW 234 & $48.46 \pm 1.42$ & $41.08 \pm 1.38(-15.23 \%)$ & $39.60 \pm 1.70(-\mathbf{1 8 . 2 8} \%)$ & $31.97 \pm 4.38(-\mathbf{3 4 . 0 3} \%)$ \\
\hline \multirow{2}{*}{$\mathrm{PH}(\mathrm{cm})$} & $\mathrm{H}+26$ & $107.67 \pm 1.41$ & $108.50 \pm 0.71(\mathbf{0 . 7 8 \%})$ & $104.17 \pm 1.65(-3.25 \%)$ & $100.17 \pm 1.18(-06.97 \%)$ \\
\hline & HUW 234 & $89.33 \pm 3.77$ & $87 \pm 1.89(-\mathbf{2 . 6 1} \%)$ & $79.17 \pm 0.24(-11.37 \%)$ & $75.67 \pm 0.47(-\mathbf{1 5 . 2 9 \% )}$ \\
\hline \multirow{2}{*}{$\mathrm{PL}(\mathrm{cm})$} & $\mathrm{H}+26$ & $34 \pm 0.47$ & $32.33 \pm 0.94(-4.91 \%)$ & $31.50 \pm 0.24(-7.38 \%)$ & $29.50 \pm 0.24(-13.24 \%)$ \\
\hline & HUW 234 & $36.17 \pm 3.54$ & $30.67 \pm 5.66(-15.21 \%)$ & $30.83 \pm 0.24(-14.76 \%)$ & $30.67 \pm 1.89(-\mathbf{1 5 . 2 1} \%)$ \\
\hline \multirow{2}{*}{ PY (g) } & $\mathrm{H}+26$ & $52.71 \pm 0.95$ & $48.79 \pm 0.69(-7.44) \%$ & $47.25 \pm 0.25(-10.36 \%)$ & $41.37 \pm 0.11(-21.51 \%)$ \\
\hline & HUW 234 & $86.72 \pm 1.80$ & $67.07 \pm 2.59(-\mathbf{2 2 . 6 6 \% )}$ & $66.81 \pm 0.58(-22.96 \%)$ & $51.47 \pm 0.25(-\mathbf{4 0 . 6 5 \% )}$ \\
\hline \multirow{2}{*}{$\mathrm{SL}(\mathrm{cm})$} & $\mathrm{H}+26$ & $12.50 \pm 0.24$ & $12.50 \pm 0.24(0 \%)$ & $11.67 \pm 00(-6.64 \%)$ & $10.83 \pm 0.71(-\mathbf{1 3 . 3 6 \% )}$ \\
\hline & HUW 234 & $9.67 \pm 00$ & $10 \pm 00(3.41 \%)$ & $8.67 \pm 00(-\mathbf{1 0 . 3 4 \% )}$ & $9.33 \pm 00(-3.52 \%)$ \\
\hline \multirow{2}{*}{ SPS } & $\mathrm{H}+26$ & $45.58 \pm 1.58$ & $44.28 \pm .49(-2.85 \%)$ & $41.89 \pm 0.45(-8.10 \%)$ & $39.77 \pm 0.81(-12.75 \%)$ \\
\hline & HUW 234 & $50.18 \pm 0.59$ & $48.72 \pm 0.11(-2.91 \%)$ & $47.52 \pm 0.45(-5.30 \%)$ & $45.81 \pm 1.47(-8.71 \%)$ \\
\hline \multirow{2}{*}{ SS (\%) } & $\mathrm{H}+26$ & $8.48 \pm 3.87$ & $6.37 \pm 3.30(-2.11 \%)$ & $10.08 \pm 2.69(\mathbf{1 . 6 0} \%)$ & $8.07 \pm 1.87(-\mathbf{0 . 4 1} \%)$ \\
\hline & HUW 234 & $3.47 \pm 1.74$ & $15.40 \pm 2.93(\mathbf{1 1 . 9 3 \% )}$ & $16.79 \pm 3.94(\mathbf{1 3 . 3 2} \%)$ & $30.13 \pm 11.67(\mathbf{2 6 . 6 6 \% )}$ \\
\hline \multirow{2}{*}{ TKW (g) } & $\mathrm{H}+26$ & $24.37 \pm 0.16$ & $23.26 \pm 0.13(-4.56 \%)$ & $21.22 \pm 0.26(-12.93 \%)$ & $20.25 \pm 0.66(-16.91 \%)$ \\
\hline & HUW 234 & $44.78 \pm 1.19$ & $36.33 \pm 3.13(-18.87 \%)$ & $40.05 \pm 1.25(-\mathbf{1 0 . 5 6} \%)$ & $34.23 \pm 0.93(-23.56 \%)$ \\
\hline
\end{tabular}

Table 2. Performance of parents T. aestivum (HUW234) and T. spelta $(\mathrm{H}+26)$ under different stress treatments and environments. The percent values in parenthesis represent the change from control.

ments over different environments (years). Also, different treatments and their combinations had differential effects on various traits studied.

Parent 1 (T. spelta $\mathrm{H}+26)$ appeared to be a tolerant genotype as the magnitudes of trait deviations from control treatments were less for parent 1 compared to parent 2 (T. aestivum HUW234) under both the individual stresses and also under the combined stress (Table 2). The performances of the RIL population and parents for various physiological, agronomical, disease and yield traits under the three stress regimes (individually and their combination), are presented in Table 3a. The data clearly revealed that traits including $\mathrm{DH}$, peduncle length (PL), plant height (PH), spike length (SL) and spikelets per spike (SPS) exhibited variation similar to the control under spot blotch stress; however, these traits showed major decline under both terminal heat and the combined stresses (Table $3 \mathrm{~b}$ ). The combined effect of both stresses reduced DH by $14.2 \%$; PH by $11.5 \%$; PL by $15.2 \%$ and SL by $4.3 \%$ compared to the control (Table $3 \mathrm{~b}$ ). Biomass (BM) was significantly reduced under all three regimes; plants exposed to the combined stresses showed the highest reduction (27.1\%), while spot blotch stress or heat stress led individually to $13.2 \%$ and $20.6 \%$ reduction respectively. Average reductions in the number of grains per spike (GPS) were $13.0 \%, 19.1 \%$ and $25.6 \%$ under the impact of spot blotch, terminal heat stress and their combination. Spot blotch and terminal heat stress reduced TKW by $17.6 \%$ and $20.9 \%$, respectively; however, the effect of combined treatment was far more detrimental with a decline of $31.8 \%$ compared to the control. The average PY decreased respectively by $21.9 \%, 27.7 \%$ and $39.0 \%$ under spot blotch, terminal heat stress and their combination. Similarly, SPS was reduced under all three stress treatments with maximum reduction shown by a combination of spot blotch with heat stress (11.4\%), followed by heat stress (10.4\%) and spot blotch (6.0\%). All the three stresses-spot blotch, terminal heat stress and their combination-resulted in mean spikelet sterility (SS) increases by $6.8 \%, 9.2 \%$ and $14.9 \%$ respectively compared to control (Table $3 \mathrm{~b}$ ). Under control (fungicide protected) conditions, disease progress (AUDPC) was estimated to be very low, whereas under individual spot blotch stress, mean AUDPC was estimated to be 667.6 showing $256.4 \%$ increased disease progression over the control. Disease infection increased further to 781.9 under combined spot blotch plus terminal heat stresses, with $317.6 \%$ increase over the control. Overall, the combination of terminal heat and spot blotch had substantially higher impact on the tested wheat lines than the either single stress regime.

Correlation analysis under the combined treatment of spot blotch and terminal heat stress. Correlation analysis among the studied traits was carried out separately for each stress regime including the control. The results of the correlation study under control treatment are presented in Fig. 1a while those 


\begin{tabular}{|c|c|c|c|c|c|}
\hline \multirow[b]{2}{*}{ Trait } & \multirow[b]{2}{*}{ General statistics } & \multicolumn{4}{|c|}{ Treatments and environments } \\
\hline & & $\begin{array}{l}\text { Control (Timely sown } \\
\text { protected with fungicide) }\end{array}$ & $\begin{array}{l}\text { Spot blotch stress (Timely } \\
\text { sown inoculated with } \\
\text { pathogen) }\end{array}$ & $\begin{array}{l}\text { Terminal Heat stress } \\
\text { (Late sown protected with } \\
\text { fungicide) }\end{array}$ & $\begin{array}{l}\text { Spot blotch + Terminal } \\
\text { heat stress (Late sown and } \\
\text { inoculated with pathogen) }\end{array}$ \\
\hline \multicolumn{6}{|l|}{$\mathbf{a}$} \\
\hline \multirow{2}{*}{ AUDPC } & Range & $92.09-304.30$ & $226.19-899.74$ & $158.65-347.69$ & $381.64-1221.08$ \\
\hline & Mean \pm SD & $194.53 \pm 39.08$ & $667.62 \pm 109.67$ & $245.10 \pm 42.45$ & $781.69 \pm 122.02$ \\
\hline \multirow{2}{*}{$\mathrm{BM}(\mathrm{g})$} & Range & $96.67-196.67$ & $83.33-190.00$ & $83.33-176.67$ & $81.67-168.33$ \\
\hline & Mean \pm SD & $140.31 \pm 15.38$ & $121.77 \pm 14.27$ & $111.37 \pm 13.08$ & $102.24 \pm 9.66$ \\
\hline \multirow{2}{*}{$\mathrm{DH}(\mathrm{d})$} & Range & $71.00-111$ & $71.00-110.33$ & $59.83-105.33$ & $52.67-102.83$ \\
\hline & Mean \pm SD & $77.08 \pm 3.31$ & $77.16 \pm 3.42$ & $66.34 \pm 3.64$ & $66.18 \pm 3.55$ \\
\hline \multirow{2}{*}{ GI } & Range & $1.00-5.00$ & $5.00-1.00$ & $1.00-5.00$ & $1.00-5.00$ \\
\hline & Mean \pm SD & $2.48 \pm 0.92$ & $2.56 \pm 1.00$ & $2.44 \pm 0.82$ & $2.61 \pm 0.80$ \\
\hline \multirow{2}{*}{ GPS } & Range & $41.66-60.47$ & $31.13-55.11$ & $32.67-50.44$ & $29.45-46.65$ \\
\hline & Mean \pm SD & $51.16 \pm 3.48$ & $44.50 \pm 4.15$ & $41.37 \pm 3.72$ & $38.05 \pm 3.67$ \\
\hline \multirow{2}{*}{$\mathrm{PH}(\mathrm{cm})$} & Range & $69.33-107.67$ & $74.00-108.50$ & $63.17-104.17$ & $64.50-100.17$ \\
\hline & Mean \pm SD & $83.77 \pm 4.98$ & $84.01 \pm 4.79$ & $74.22 \pm 4.75$ & $74.10 \pm 4.82$ \\
\hline \multirow{2}{*}{ PL (cm) } & Range & $21.83-37.50$ & $22.50-41.83$ & $17.50-37.00$ & $16.67-37.67$ \\
\hline & Mean \pm SD & $29.33 \pm 2.74$ & $29.28 \pm 2.83$ & $25.00 \pm 3.21$ & $24.89 \pm 3.11$ \\
\hline \multirow{2}{*}{ PY (g) } & Range & $42.39-100.23$ & $35.50-82.02$ & $36.91-75.29$ & $27.93-60.90$ \\
\hline & Mean \pm SD & $74.40 \pm 8.44$ & $58.08 \pm 7.72$ & $53.77 \pm 6.83$ & $45.40 \pm 5.28$ \\
\hline \multirow{2}{*}{$\mathrm{SL}(\mathrm{cm})$} & Range & $8.00-12.50$ & $7.83-12.50$ & $6.50-11.67$ & $6.83-11.50$ \\
\hline & Mean \pm SD & $9.77 \pm 0.73$ & $10.04 \pm 0.73$ & $9.28 \pm 0.78$ & $9.35 \pm 0.72$ \\
\hline \multirow{2}{*}{ SPS } & Range & $45.58-64.50$ & $43.68-60.24$ & \begin{tabular}{|l|}
$41.89-57.77$ \\
\end{tabular} & $39.77-57.51$ \\
\hline & Mean \pm SD & $54.91 \pm 3.12$ & $51.60 \pm 3.12$ & $49.23 \pm 2.56$ & $48.63 \pm 2.55$ \\
\hline \multirow{2}{*}{ SS (\%) } & Range & $1.40-15.77$ & $1.19-37.87$ & $3.79-30.55$ & $5.35-38.48$ \\
\hline & Mean \pm SD & $6.80 \pm 3.08$ & $13.64 \pm 5.86$ & $15.96 \pm 5.58$ & $21.74 \pm 6.91$ \\
\hline \multirow{2}{*}{ TKW (g) } & Range & $24.37-52.37$ & $23.16-40.66$ & $19.41-40.05$ & $19.99-34.23$ \\
\hline & Mean \pm SD & $37.67 \pm 3.76$ & $31.04 \pm 3.08$ & $29.78 \pm 3.49$ & $25.68 \pm 2.83$ \\
\hline \multicolumn{6}{|l|}{$\mathbf{b}$} \\
\hline \multirow{3}{*}{ AUDPC } & Mean & 194.53 & 667.62 & 245.10 & 781.69 \\
\hline & \% Change over control & & 256.35 & 29.49 & 317.61 \\
\hline & $\begin{array}{l}\text { Range of change over control } \\
\text { (\%) }\end{array}$ & & 91.89 to 658.03 & -25.88 to 130.47 & 144.31 to 683.60 \\
\hline \multirow{3}{*}{$\mathrm{BM}(\mathrm{g})$} & Mean & 140.310 & 121.770 & 111.370 & 102.240 \\
\hline & \% Change over control & & -13.21 & -20.63 & -27.13 \\
\hline & $\begin{array}{l}\text { Range of change over control } \\
(\%)\end{array}$ & & -38.60 to 20.97 & -43.82 to 4.53 & -49.12 to -6.90 \\
\hline \multirow{3}{*}{$\mathrm{DH}(\mathrm{d})$} & Mean & 77.080 & 77.160 & 66.340 & 66.180 \\
\hline & \% Change over control & & 0.09 & -13.94 & -14.15 \\
\hline & $\begin{array}{l}\text { Range of change over control } \\
\text { (\%) }\end{array}$ & & -9.36 to 10.39 & -19.14 to -5.11 & -30.24 to -3.46 \\
\hline \multirow{3}{*}{ GI } & Mean & 2.480 & 2.560 & 2.440 & 2.610 \\
\hline & \% Change over control & & 3.51 & 1.56 & 5.56 \\
\hline & $\begin{array}{l}\text { Range of change over control } \\
(\%)\end{array}$ & & -61.54 to 125 & -40 to 100 & -55.56 to 175 \\
\hline \multirow{3}{*}{ GPS } & Mean & 51.160 & 44.500 & 41.370 & 38.050 \\
\hline & \% Change over control & & -13.01 & -19.13 & -25.63 \\
\hline & $\begin{array}{l}\text { Range of change over control } \\
(\%)\end{array}$ & & -36.00 to -0.54 & -34.76 to -5.60 & -40.72 to -9.42 \\
\hline & Mean & 83.770 & 84.010 & 74.220 & 74.100 \\
\hline $\mathrm{PH}(\mathrm{cm})$ & \% Change over control & & 0.29 & -11.39 & -11.54 \\
\hline & $\begin{array}{l}\text { Range of change over control } \\
(\%)\end{array}$ & & -14.86 to 21.88 & -22.47 to 0.72 & -26.86 to 7.21 \\
\hline & Mean & 29.330 & 29.280 & 25.000 & 24.890 \\
\hline PL (cm) & \% Change over control & & -0.16 & -14.75 & -15.15 \\
\hline & $\begin{array}{l}\text { Range of change over control } \\
(\%)\end{array}$ & & -31.12 to 29.38 & -36.26 to 14.94 & -48.98 to 20.78 \\
\hline
\end{tabular}




\begin{tabular}{|c|c|c|c|c|c|}
\hline \multirow[b]{2}{*}{ Trait } & \multirow[b]{2}{*}{ General statistics } & \multicolumn{4}{|c|}{ Treatments and environments } \\
\hline & & $\begin{array}{l}\text { Control (Timely sown } \\
\text { protected with fungicide) }\end{array}$ & $\begin{array}{l}\text { Spot blotch stress (Timely } \\
\text { sown inoculated with } \\
\text { pathogen) }\end{array}$ & $\begin{array}{l}\text { Terminal Heat stress } \\
\text { (Late sown protected with } \\
\text { fungicide) }\end{array}$ & $\begin{array}{l}\text { Spot blotch + Terminal } \\
\text { heat stress (Late sown and } \\
\text { inoculated with pathogen) }\end{array}$ \\
\hline \multirow{3}{*}{ PY (g) } & Mean & 74.400 & 58.080 & 53.770 & 45.400 \\
\hline & \% Change over control & & -21.93 & -27.72 & -38.97 \\
\hline & \begin{tabular}{|l}
$\begin{array}{l}\text { Range of change over control } \\
(\%)\end{array}$ \\
\end{tabular} & & -39.90 to -5.47 & -45.57 to -10.36 & -54.84 to 21.51 \\
\hline \multirow{3}{*}{$\mathrm{SL}(\mathrm{cm})$} & Mean & 9.770 & 10.040 & 9.280 & 9.350 \\
\hline & \% Change over control & & 2.73 & -5.09 & -4.31 \\
\hline & $\begin{array}{l}\text { Range of change over control } \\
(\%)\end{array}$ & & -24.32 to 33.96 & -24.19 to 14.81 & -32.79 to 23.21 \\
\hline \multirow{3}{*}{ SPS } & Mean & 54.910 & 51.600 & 49.230 & 48.630 \\
\hline & \% Change over control & & -6.02 & -10.35 & -11.44 \\
\hline & $\begin{array}{l}\text { Range of change over control } \\
(\%)\end{array}$ & & -23.52 to 11.29 & -22.29 to 2.66 & -26.90 to 4.05 \\
\hline \multirow{3}{*}{ SS (\%) } & Mean & 6.800 & 13.640 & 15.960 & 21.740 \\
\hline & \% Change over control & & 6.84 & 9.16 & 14.94 \\
\hline & $\begin{array}{l}\text { Range of change over control } \\
(\%)\end{array}$ & & -3.37 to 30.54 & -4.12 to 24.30 & -0.41 to 31.67 \\
\hline \multirow{3}{*}{ TKW (g) } & Mean & 37.670 & 31.040 & 29.780 & 25.680 \\
\hline & $\%$ Change over control & & -17.60 & -20.94 & -31.82 \\
\hline & $\begin{array}{l}\text { Range of change over control } \\
(\%)\end{array}$ & & -43.65 to -4.53 & -42.46 to -5.50 & -53.49 to -11.43 \\
\hline
\end{tabular}

Table 3. a Mean and range of various traits studied under different treatments and environments. $b$ Effect of spot blotch, terminal heat stress and their combination on various traits studies in comparison to the control.

under individual spot blotch, terminal heat stress treatment and combination of spot blotch and terminal heat stress are presented in Figs. 1b,c,d respectively.

In the following, ${ }^{* *}$ denotes $P<0.01$ while ${ }^{*}$ indicates $P<0.05$. Under the combined stress condition, $\mathrm{DH}$ was positively correlated with $\mathrm{PH}\left(0.36^{* *}\right)$ and $\mathrm{BM}\left(0.34^{* *}\right)$. A highly significant negative correlation of $\mathrm{DH}$ was observed with AUDPC $\left(-0.39^{* *}\right)$, TKW $\left(-0.38^{* *}\right)$ and PY $\left(-0.28^{* *}\right)$. PH showed highly significant correlation with PL $\left(0.58^{\star *}\right), \mathrm{BM}\left(0.4^{\star *}\right)$ and SL $\left(0.21^{\star *}\right)$. Highly significant negative correlation $\left(-0.24^{\star *}\right)$ was found for $\mathrm{PH}$ and AUDPC. PL was positively correlated with BM $\left(0.32^{* *}\right)$, PY $\left(0.29^{* *}\right)$, TKW $\left(0.28^{* *}\right)$ and SL $\left(0.17^{\star *}\right)$. SL showed positive correlation with biomass $\left(0.2^{* *}\right)$ and GPS $\left(0.14^{*}\right)$. BM showed a high degree of positive correlation with PY $\left(0.41^{* *}\right)$ and TKW $\left(0.21^{* *}\right)$. A significant negative association was found between BM and AUDPC $\left(-0.29^{* *}\right)$. GPS demonstrated a high positive correlation with SPS $\left(0.42^{* *}\right)$ and PY $\left(0.40^{* *}\right)$ while a very high degree of negative correlation was detected with SS $\left(-0.84^{* *}\right)$ and AUDPC $\left(-0.14^{* *}\right)$. TKW was found to be in a very high positive correlation with PY $\left(0.54^{* *}\right)$. Significant negative association of PY was observed with SS $\left(-0.29^{* *}\right)$ and AUDPC $\left(-0.17^{\star}\right)$. SPS was positively correlated with SS $\left(0.13^{*}\right)$ while SPS showed a negative correlation with AUDPC (-0.12); SS also showed a moderate positive correlation with AUDPC (0.09). The highest degree of negative correlation of AUDPC was found with DH $\left(-0.39^{* *}\right)$ followed by BM $\left(-0.29^{* *}\right), \mathrm{PH}\left(-0.24^{* *}\right)$, PY $\left(-0.17^{*}\right)$ and GPS $\left(-0.14^{*}\right)$. Glaucousness Index $(\mathrm{GI})$ had little impact.

Multivariate analysis. Principal component analysis (PCA) showed eigenvalues $>1$ for the first five components under the control environment. The first and second principal components (PC1 and PC2) explained a total of $33.6 \%$ phenotypic variation; PC1 and PC 2 explained $18.0 \%$ and $15.6 \%$ variations, respectively. Major contributors to these two PCAs were GPS, PY, SPS, BM, PL, PH and SS (Fig. 2a). Under spot blotch treatment, the first five principal components had eigenvalues $>1$, where PC1 and PC2 explained $18.1 \%$ and $16.0 \%$ of the phenotypic variation. Thus, the first two principal components (PC1 and PC2) cumulatively explained 34.1\% variation; major contributors were GPS, SS, PY, PH, PL, SPS, TKW, and SL (Fig. 2b).

Under terminal heat stress a cumulative phenotypic variation of $41.1 \%$ was explained by PC1 (27.7\%) and PC2 (13.4\%) where PCA demonstrated that the first five principal components had eigenvalues $>1$. The major contributors to the first two PCs under terminal heat stress environment were GPS, SS, BM, PH, PY, PL and TKW (Fig. 2c). Under combined treatment of spot blotch and terminal heat stress, the first five principal components had eigenvalues $>1$ with PC1 and PC2 explaining 30.9\% and $12.1 \%$ phenotypic variation, respectively. The main contributors to the $43.0 \%$ variation explained cumulatively by PC1 and PC2 were GPS, SPS, BM, PH, PL, TKW and PY (Fig. 2d).

Grain yield superiority and stress tolerance indices. Grain yield superiority and stress tolerance indices for the top five RILs compared to those for the best local variety HUW234 (parent 2), are presented in Table 4. All the top five lines for spot blotch tolerance showed Disease Tolerance Index (DTI) values significantly greater than that of HUW234, and had grain yields of 110.3-117.3\% compared to the mean yield of HUW234. Similarly, all the top five lines selected based on Heat Tolerance Index (HTI) values showed yields of 103.7$111.6 \%$ compared to the mean yield of HUW234 under terminal heat stress. The data also showed that the top 
a
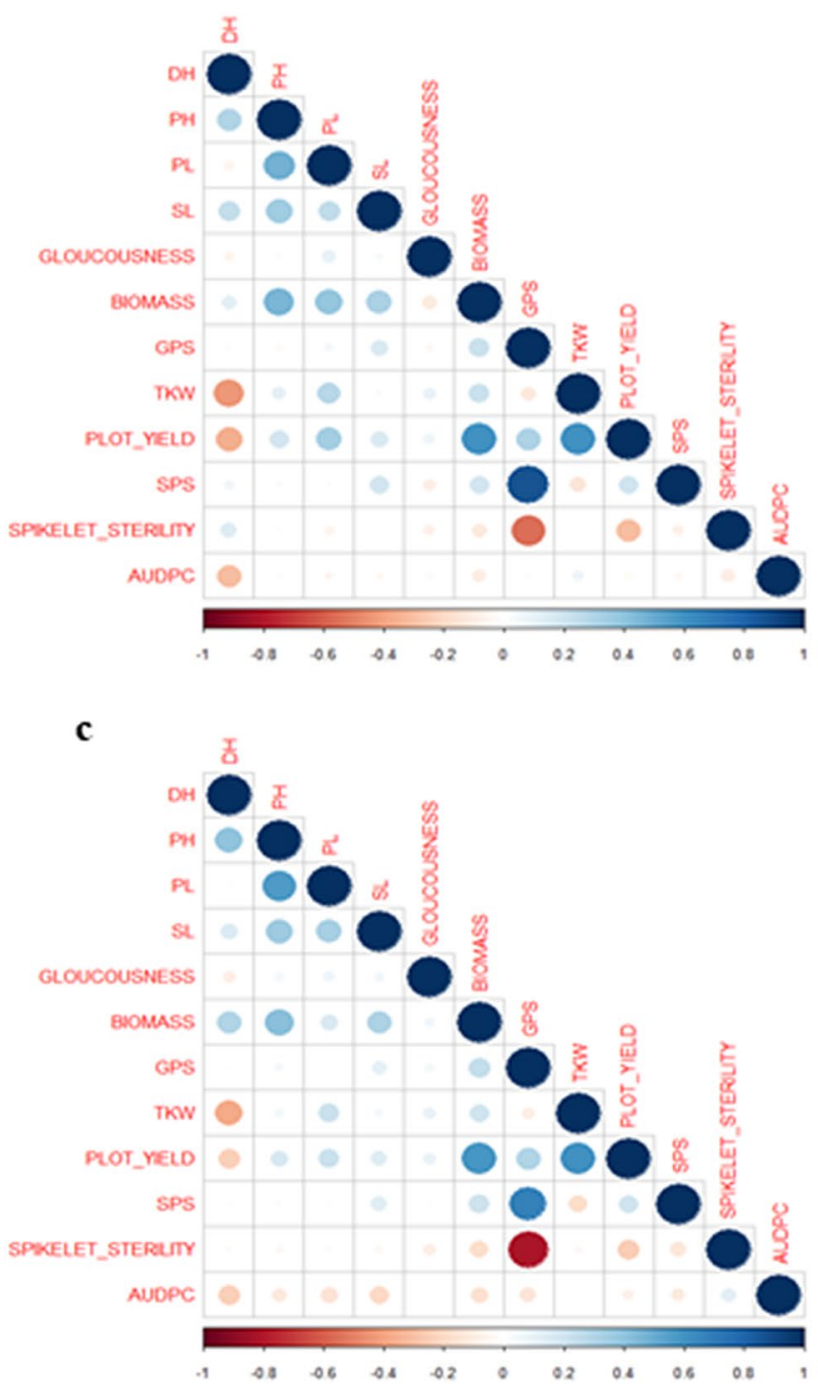

b
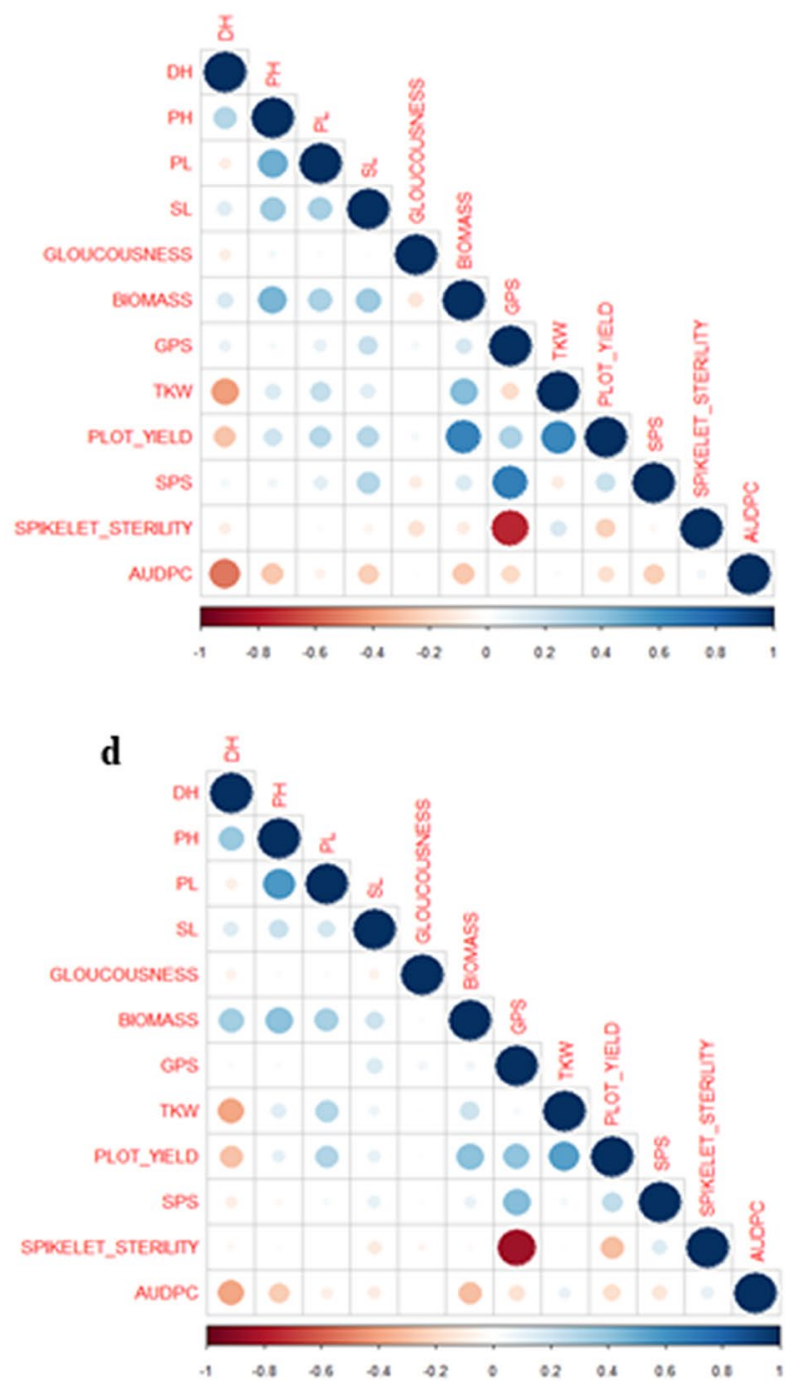

Figure 1. Correlation among traits in control (a); spot blotch (b); terminal heat stress (c); and combined stresses of spot blotch and terminal heat $(\mathbf{d})$.

five lines that exhibited better tolerance to combined stress (terminal heat plus spot blotch), all had significantly superior Heat and Disease Tolerance Index (HDTI) value as compared to HUW234. Notably, four of these lines exhibited yields of $110.5-113.4 \%$ of the mean yield of HUW234 under the combined stresses. The top-ranked genotypes performing better under the individual stress of spot blotch disease as well as under the combined stress of spot blotch with terminal heat were lines 64, 71, and 139, while lines 64 and 175 had better tolerance to terminal heat stress alone as well as to the combined stress. Under simultaneous spot blotch and terminal heat stresses, lines $64,71,123,139$, and 175 were superior based on their tolerance indices. Of these, four lines-64, 71, 123, and 175-were also superior in performance to HUW234. Line 64 was the top performer against both of the individual stresses and the combined stress.

\section{Discussion}

In the present study, a RIL population derived from the cross T. spelta $\times$ T. aestivum was analyzed to identify possible superior wheat lines against spot blotch, terminal heat stress and combined spot blotch plus terminal heat stress. T. spelta was chosen as it has been identified as one of the most resistant genotypes for biotic and abiotic stresses ${ }^{24}$. It has also been demonstrated that $T$. spelta wheat lines possess higher activity of phenylalanine ammonia-lyase (PAL) and maintain a relatively high reactive oxygen species (ROS) content which allows them to survive better during fungal infections ${ }^{25}$. In addition, the ability of T. spelta lines to grow under limited oxygen supply makes them a potential source for improving the stress tolerance of wheat ${ }^{22}$. Our study was able to identify four T. spelta-derived wheat lines that performed well under both the experimental stresses and their combination, which further supports the use of T. spelta as a breeding parent for enhancing stress tolerance against spot blotch and terminal heat. 
a

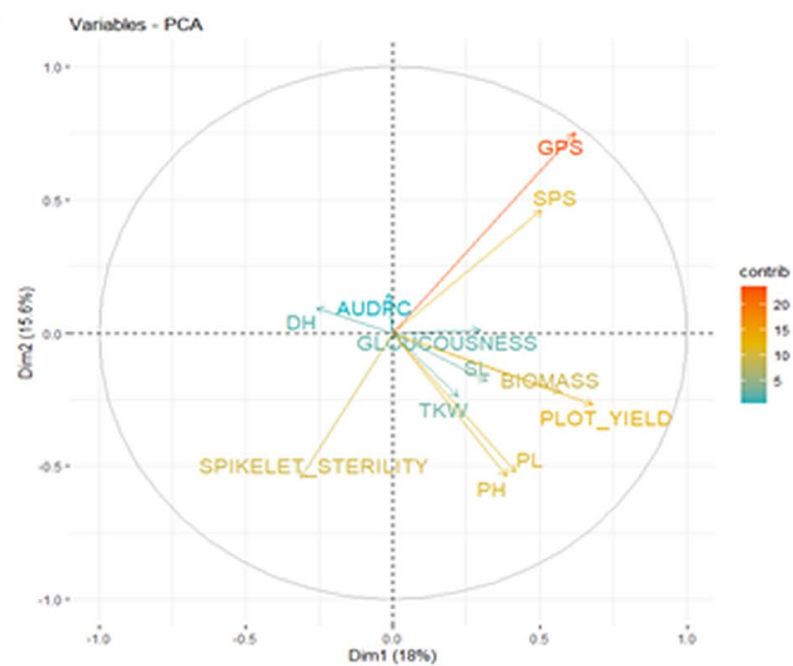

c

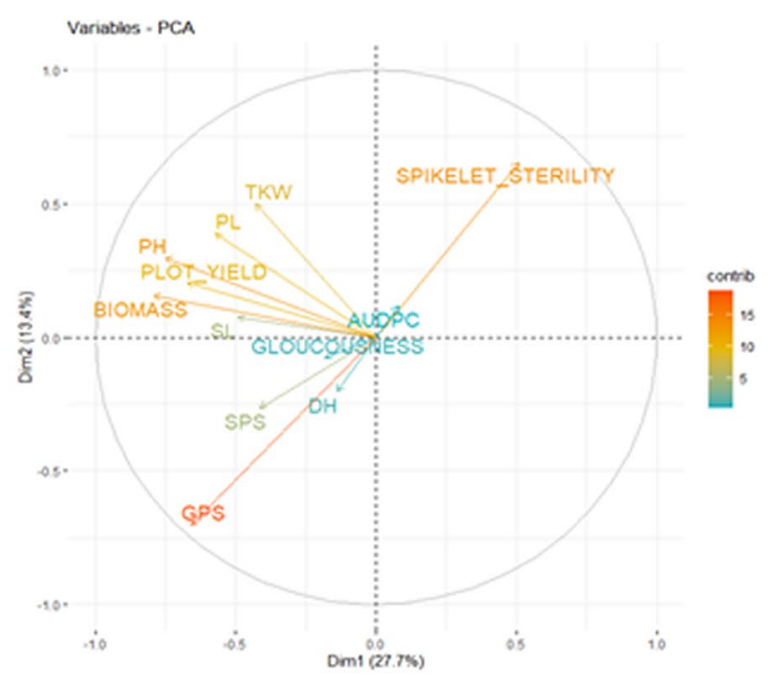

b

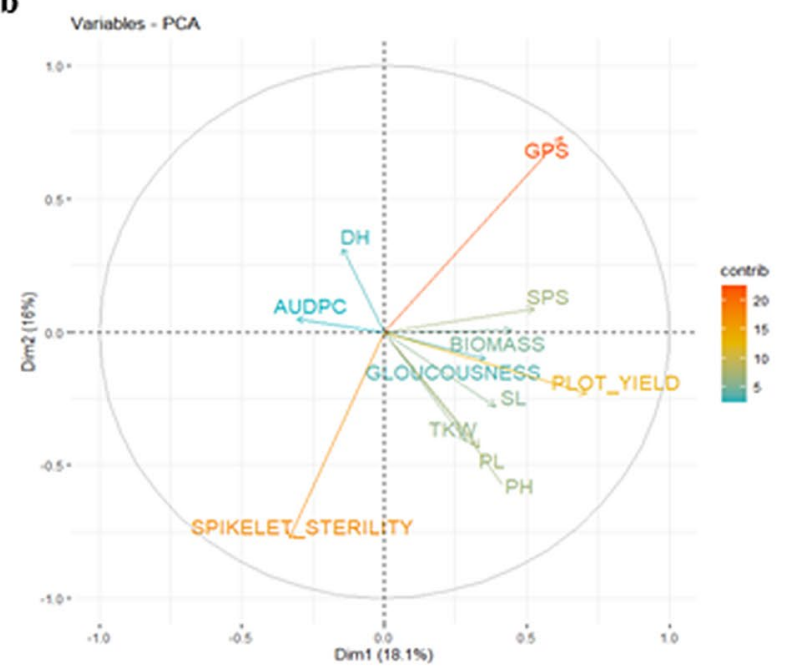

d

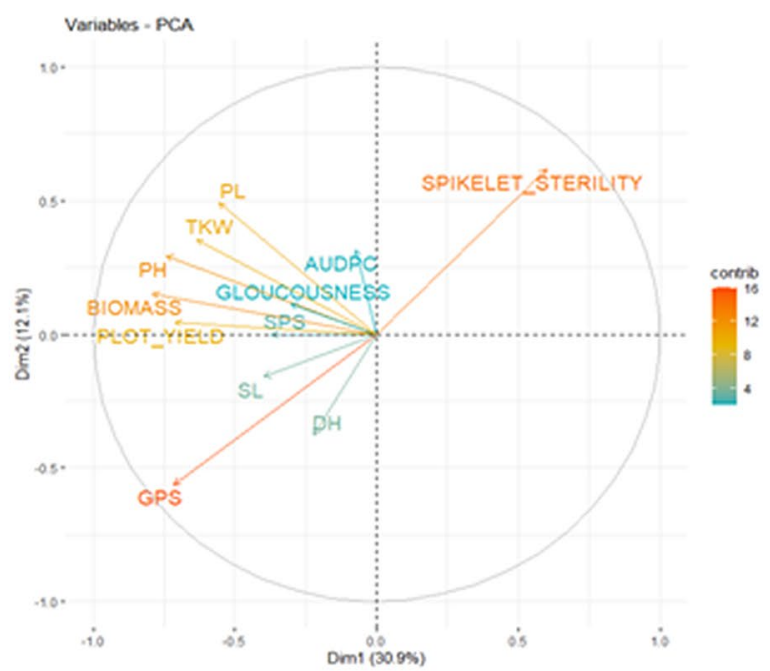

Figure 2. Principal Component Analysis Biplot for traits studied under control (a); spot blotch (b); terminal heat stress (c); and combined stresses of spot blotch and terminal heat (d).

\begin{tabular}{|c|c|c|c|c|c|c|c|c|c|c|c|c|c|c|c|c|}
\hline \multirow[b]{2}{*}{$\begin{array}{l}\text { Rank of } \\
\text { genotypes }\end{array}$} & \multicolumn{6}{|c|}{ Spot blotch } & \multicolumn{4}{|c|}{ Terminal heat } & \multicolumn{6}{|c|}{ Spot blotch and terminal heat } \\
\hline & Genotype & DTI & $\begin{array}{l}\text { AVG } \\
\text { Yield } \\
\text { (g) }\end{array}$ & $\begin{array}{l}\text { Grain } \\
\text { yield } \\
\text { over } \\
\text { local } \\
\text { check } \\
\text { (\%) }\end{array}$ & $\begin{array}{l}\text { AVG. } \\
\text { AUDPC }\end{array}$ & $\begin{array}{l}\text { AUDPC } \\
\text { over } \\
\text { local } \\
\text { check } \\
(\%)\end{array}$ & Genotype & HTI & $\begin{array}{l}\text { AVG } \\
\text { Yield } \\
\text { (g) }\end{array}$ & $\begin{array}{l}\text { Grain } \\
\text { yield } \\
\text { over } \\
\text { local } \\
\text { check } \\
(\%)\end{array}$ & Genotype & HDTI & $\begin{array}{l}\text { AVG } \\
\text { Yield } \\
\text { (g) }\end{array}$ & $\begin{array}{l}\text { Grain } \\
\text { yield } \\
\text { over } \\
\text { local } \\
\text { check } \\
(\%)\end{array}$ & $\begin{array}{l}\text { AVG } \\
\text { AUDPC }\end{array}$ & $\begin{array}{l}\text { AUDPC } \\
\text { over local } \\
\text { check(\%) }\end{array}$ \\
\hline 1 & 64 & 1.48 & 78.7 & 17.3 & 568.69 & -32.87 & 89 & 1.31 & 78.2 & 11.6 & 64 & 1.10 & 60.9 & 10.5 & 640.29 & -42.15 \\
\hline 2 & 21 & 1.26 & 77.1 & 14.8 & 485.08 & -42.74 & 64 & 1.23 & 76.1 & 8.6 & 123 & 0.90 & 60.9 & 10.6 & 725.48 & -34.45 \\
\hline 3 & 139 & 1.21 & 74.2 & 10.6 & 558.16 & -34.11 & 58 & 1.22 & 72.7 & 3.7 & 175 & 0.88 & 62.5 & 13.4 & 527.46 & -52.34 \\
\hline 4 & 32 & 1.20 & 74.1 & 10.4 & 488.22 & -42.37 & 175 & 1.19 & 75.3 & 7.4 & 71 & 0.88 & 62.3 & 13.1 & 509.31 & -53.98 \\
\hline 5 & 71 & 1.18 & 74.0 & 10.3 & 421.76 & -50.21 & 32 & 1.13 & 76.0 & 8.4 & 139 & 0.88 & 53.8 & -2.3 & 634.06 & -42.71 \\
\hline P1 & $\mathrm{H}+26$ & 0.47 & 58.7 & -12.4 & 226.19 & -73.30 & $\mathrm{H}+26$ & 0.45 & 57.2 & -18.3 & $\mathrm{H}+26$ & 0.40 & 50.3 & -8.6 & 381.64 & -65.52 \\
\hline $\mathrm{P} 2$ & HUW234 & 1.05 & 67.1 & & 847.12 & & HUW234 & 1.05 & 70.1 & & HUW234 & 0.81 & 55.1 & & 1106.78 & \\
\hline C.D.(0.05) & & 0.10 & 4.6 & & & & & 0.10 & 4.9 & & & 0.10 & 4.0 & & & \\
\hline C.D.(0.01) & & 0.10 & 6.3 & & & & & 0.10 & 6.8 & & & 0.10 & 5.4 & & & \\
\hline
\end{tabular}

Table 4. Best RILs of T. spelt $\times$ T. aestivum based on grain yield under different stress treatments. The trait abbreviations are: DTI: Disease Tolerance index: HTI: Heat Tolerance Index: HDTI: Heat + Disease Tolerance Index. 
The present study has also provided detail insights about the impacts of spot blotch, terminal heat and their combination on various traits of wheat. All three stresses drastically reduced overall yield of the wheat lines tested. Interestingly, a few phenological and plant architecture-related traits like DH, PH, PL and SL were not greatly affected by the individual treatment of spot blotch. However, these traits were significantly reduced under the individual stress of terminal heat and the combined stress of spot blotch plus terminal heat. This emphasizes the fact that the detrimental effects of combined spot blotch and terminal heat stress are not necessarily additive on phenological and architecture-related traits; the reduction in these traits appears to be solely brought about by terminal heat stress. It has been proven that terminal heat stress is responsible for the abortion of anthers, decreased grain weight, reduced photosynthesis translocation and starch accumulation, thus decreasing overall wheat production ${ }^{26,27}$. The combination of spot blotch and terminal heat severely reduced PY followed by TKW, $\mathrm{BM}$ and GPS compared to individual treatments of heat or spot blotch. Spot blotch reduces the total photosynthetically active leaf area, which coupled with terminal heat stress stimulates premature leaf senescence too ${ }^{28}$. Heat stress causes disturbance in photosynthetic machinery and assimilate supply duration that ultimately lowers the yield ${ }^{29}$. Heat stress also causes oxidative stress damage through excess production of reactive oxygen species $(\text { ROS })^{30,31}$, which might be true even when heat stress occurs in combination with spot blotch. Occurrence of high temperature stress at meiosis results in impaired gametogenesis fertility, which causes reduced grain filling ${ }^{30}$. Thus, it is plausible that the suboptimal photosynthesis, poor photosynthates mobilization and reduced grain filling duration caused by the combination of spot blotch and terminal heat stresses is responsible for increasing sterility and reduction in grain yield and biomass accumulation. This finding is consistent with previous observations where a combined effect of spot blotch and terminal heat stress caused significant premature senescence of leaves, reduced grain filling, kernel weight and seed set ${ }^{11,19,32,33}$. However, future investigations are needed to elucidate the molecular and physiological aspects of combined effect of spot blotch and terminal heat stress.

The AUDPC for spot blotch was found to increase when the disease coincided with high temperature stress. Since spot blotch pathogen is more aggressive in late sown conditions, high temperature stress combined with spot blotch at the reproductive phase seems to be major factor that contribute to reducing wheat yield ${ }^{32}$. In agreement, our data shows that under the late sown condition an additive action of spot blotch and terminal heat significantly reduced wheat yield compared to the individual regimes of spot blotch or terminal heat. Since both these stresses have more impact when the wheat crop is in transition from vegetative to reproductive phase, they jointly hamper the grain formation and grain filling processes to reduce grain yield. Genotypes with early flowering capability can finish most of their reproductive processes before spot blotch and heat stress or their combination become intense. A negative correlation was reported between $\mathrm{DH}$ and spot blotch severity ${ }^{34}$, but the impact of terminal heat was not studied ${ }^{35-37}$.

In our study, all the stress treatments showed significant negative correlation of DH with PY and TKW. This supports the hypothesis that early flowering genotypes may perform better under spot blotch infection, heat stress and their combination, due to their potential to escape most of the stressed period ${ }^{38,39}$. SS is another trait that had a highly significant negative correlation with GPS and PY. Since the effect of both spot blotch and terminal heat become more severe at the reproductive stage, it is plausible that these stresses may be responsible for the production of structurally abnormal and non-functional florets ${ }^{40}$. A case of pollen abortion by heat stress has been reported in wheat ${ }^{30}$. Further, high-temperature stress at the anthesis and post-anthesis stages has been reported to cause a severe decline in GPS, through the hampering of spike growth and development, and by increased ovule abortion and pollen mortality ${ }^{41-45}$. Pollen cells and microspores are adversely affected by increased temperature stress at the reproductive stage in wheat, which leads to pollen sterility ${ }^{46}$.

We found some spelt-derived lines showing higher stress tolerance indices against spot blotch, terminal heat and their combination. RILs 64, 71, 123 and 175 were the genotypes most tolerant to spot blotch, terminal heat as well as to their combined stress. Interestingly, these four lines also gave higher yields under control conditions (no stress), suggesting that some genotypes have high stability and can respond well under various environment and stress conditions. This finding is in agreement with previous report where similar observations was reported for wheat lines under heat and drought stresses ${ }^{47}$. RIL64 was the top performer against all the three stress treatments and may be used in future breeding programs to enhance wheat stress tolerance in warm and humid regions of the world.

The present study has successfully utilized the potential of $T$. spelta in generating wheat lines with enhanced tolerance against spot blotch, terminal heat and their combination. The trait correlation study combined with multivariate analysis and tolerance indices provides an insight into potential selection criteria for wheat improvement against spot blotch, terminal heat and their combination. In the present study, four elite lines identified for their tolerance against these stresses may be used as parents in the future wheat breeding programmes.

\section{Methods}

Plant material and experimental conditions. A total of 187 genotypes-185 recombinant inbred lines (RILs) and their parents-were used in this study. The $\mathrm{F}_{9-10}$ RIL population was developed from the cross $T$. spelta $(\mathrm{H}+26) \times$ T. aestivum (cv. HUW234), where $\mathrm{H}+26$ was designated as $\mathrm{P} 1$ and HUW234 as $\mathrm{P} 2 . \mathrm{H}+26$ is very resistant to spot blotch and is capable of withstanding high temperatures, while HUW234 is a variety widely adopted in the North Eastern Plains Zone (NEPZ) of India and shows significant spot blotch infection rates. HUW234 is a previously leading variety that covered around 4-5 million hectares in NEPZ of India during the 1990s; it was popular due to its high yield and excellent chapati (an Indian staple bread) quality. This variety continued to dominate the NEPZ until recently; it is believed still to account for about 1 Mha in NEPZ. The T. spelta parent was tested at Varanasi for two years and was found to show high resistance to spot blotch and yield higher under terminal heat stress. 
The experimental material was evaluated at Agricultural Research Farm of Banaras Hindu University, Varanasi, India $\left(25^{\circ} 18^{\prime} \mathrm{N}, 83^{\circ} 03^{\prime} \mathrm{E}\right.$ and $\left.75.5 \mathrm{~m} \mathrm{AMSL}\right)$ for three consecutive years i.e. Rabi (winter) season 2013-14, 2014-15 and 2015-16. The mean temperatures (November-April) during these years were $25.4^{\circ} \mathrm{C}, 23.2^{\circ} \mathrm{C}$ and $24.5^{\circ} \mathrm{C}$ respectively, while the annual rainfalls were $932.7,1009.4$ and $835.5 \mathrm{~mm}$. The Varanasi Research Centre is known as a hot spot for spot blotch infection. All the 187 genotypes (RILs with parents) were sown in four different sets as follows:

(i) Timely sown protected control:

Two replications of the population (185 RILs + parents) were sown in the third week of November and treated with a systemic fungicide, azoxystrobin, to protect them from the natural occurrence of spot blotch.

(ii) Timely sown disease inoculated/Spot blotch disease treatment:

Two replications of the population (185 RILs + parents) were sown in the last week of November and inoculated with B. sorokiniana.

(iii) Late sown protected/Terminal heat stress treatment:

Two replications of the population were sown in the last week of December and protected from the natural occurrence of spot blotch by spraying with a systemic fungicide, azoxystrobin.

(iv) Late sown disease inoculated/Combined spot blotch and terminal heat stress treatment:

Two replications of the population were sown in the last week of December and inoculated with $B$. sorokiniana.

The experiment was laid out in an alpha lattice design with two replications. Each genotype was sown in two rows of two-meter-long plots under standard irrigated conditions maintaining a row-to-row distance of $20 \mathrm{~cm}$ and a plant-to-plant distance of $5 \mathrm{~cm}$. The genotypes were allocated randomly within each replication using Fisher and Yates' Random Table ${ }^{48}$. Recommended fertilizer doses $\left(120 \mathrm{~kg} \mathrm{~N}: 60 \mathrm{~kg} \mathrm{P}_{2} \mathrm{O}_{5}: 40 \mathrm{~kg} \mathrm{~K} \mathrm{O}_{2}\right.$ per ha) were applied in the field. The full amounts of $\mathrm{K}_{2} \mathrm{O}$ and $\mathrm{P}_{2} \mathrm{O}_{5}$ were supplied as a single dose at sowing, while nitrogen was provided in three split doses: $60 \mathrm{~kg}$ per ha at sowing, $30 \mathrm{~kg}$ at the time of the first irrigation [21 days after sowing (DAS)] and the remaining $30 \mathrm{~kg}$ at the time of second irrigation (45 DAS).

Preparation and application of inoculum. The artificial epiphytotic condition was created by inoculation in the field with a virulent race of B. sorokiniana. An isolate of B. sorokiniana (HD 3069/MCC 1572) was obtained from the Department of Mycology and Plant Pathology, Institute of Agricultural Sciences, Banaras Hindu University, Varanasi and applied to create an artificial infection ${ }^{49}$.This isolate was purified and multiplied on potato dextrose agar (PDA) medium. Mass culture was produced on parboiled sorghum grains under aseptic conditions $\mathrm{s}^{50}$. A spore suspension $\left(10^{4}\right.$ spore $\left.\mathrm{ml}^{-1}\right)$ was prepared and adjusted by soaking the colonized sorghum grains in distilled water, to which $100 \mu \mathrm{l}$ Tween 20 per liter had been added. The inoculation was done at the ear emergence stage (GS 55) $)^{51}$ during the evening hours ${ }^{52}$. The field was irrigated immediately after inoculation to provide the proper humidity necessary for spore germination and disease development to take place.

Data collection. Data were recorded for days to $50 \%$ heading (DH), PH, PL, SL, disease severity, GI, BM (50 randomly selected tillers), GPS (as the average number of grains from five randomly selected spikes), TKW, PY (as the yield from 50 randomly selected fertile tillers), SPS (as the average number of spikelets from five randomly selected spikes) and SS (as the average percentage of spikelets not setting seeds from five randomly selected spikes).

Disease scoring for calculating disease severity percentage and AUDPC. The quantification of spot blotch disease development was done by scoring at three different growth stages-GS 63 (beginning of anthesis to 50\%), GS 69 (complete anthesis) and GS 77 (late milking) ${ }^{53}$. The scoring on each genotype was done on a double-digit scale (D1D2, 00-99) ${ }^{52}$. The scale's first digit (D1) indicates vertical progress of disease on the plant, while the second digit (D2) indicates the severity of disease based on the total leaf area occupied by the disease symptoms. The disease score was later converted into disease severity (DS) in terms of percentage by using the formula as follows ${ }^{54}$ :

$$
\% \text { Disease Severity }=(\mathrm{D} 1 / 9) \times(\mathrm{D} 2 / 9) \times 100
$$

The corresponding disease severity percentages of each disease score taken at GS63, GS69 and GS77 were used for the area under the disease progress curve (AUDPC) calculation ${ }^{55}$ as follows:

$$
\text { AUDPC }=\sum_{\mathrm{i}=0}^{\mathrm{n}-1}\left[\left\{\frac{\mathrm{Yi}+\mathrm{Y}(\mathrm{i}+1)}{2}\right\} \times(\mathrm{t}(\mathrm{i}+1)-\mathrm{ti})\right]
$$

where $\mathrm{Yi}=$ disease level at time ti. $\{\mathrm{t}(\mathrm{i}+1)-\mathrm{ti}\}=$ Time interval (in days) between two disease scores. $\mathrm{n}=$ number of dates at which spot blotch score was recorded.

Stress Tolerance Index (STI). Stress tolerance index is an important parameter for understanding crop behavior under stress. The index was used to determine the tolerance of genotypes to stress and calculated by employing the following formula ${ }^{56}$ : 


$$
\mathrm{STI}=(\mathrm{Ys} * \mathrm{Yp}) /(\overline{\mathrm{Y}} \mathrm{p})^{2}
$$

where $\mathrm{Yp}=$ the average plot yield of particular genotype under non-stress conditions. Ys = the average plot yield of a genotype under stress conditions. $\bar{Y} p=$ the yield average of all genotypes under non-stress conditions

This was used to calculate the separate DTI (Disease Tolerance Index), HTI (Heat Tolerance index) and HDTI (Combined Heat and Disease tolerance Index). For DTI calculation, data from the timely sown disease (spot blotch) inoculated treatment was used. For HTI, data from the late sown protected/terminal heat stress (late sown protected) treatment was applied. Similarly, data from the late sown disease inoculated/combined spot blotch and terminal heat stresses (late sown disease inoculated) treatment was used for HDTI.

Statistical analysis. The significance differences between treatments and the significance of differences among the genotypes were assessed by Analysis of Variance (ANOVA) using the proc GLM procedure of SAS statistical software version 9.4 (2014). In addition, ' $\mathrm{R}$ ' software was used to perform the correlation analyses among the traits under study. The relationships between yield and other yield attributing traits were further explored using principal component analysis ${ }^{57}$. The results of the principal component analysis are presented using biplots constructed using the first two principal components for each treatment.

Received: 18 September 2020; Accepted: 12 February 2021

Published online: 16 March 2021

\section{References}

1. Shiferaw, B. et al. Crops that feed the world 10 Past successes and future challenges to the role played by wheat in global food security. Food Secur. 5, 291-317 (2013).

2. Joshi, A. K., Mishra, B., Chatrath, R., OrtizFerrara, G. \& Singh, R. P. Wheat improvement in India: present status, emerging challenges and future prospects. Euphytica 157, 431-446 (2007).

3. Villareal, R. L. Yield loss to spot blotch in spring bread wheat in warm nontraditional wheat production areas. Plant Dis. 79,893 (1995).

4. Chand, R., Pandey, S. P., Singh, H. V., Kumar, S. \& Joshi, A. K. Variability and its probable cause in natural populations of spot blotch pathogen Bipolaris sorokiniana of wheat (T. aestivum L.) in India / Variabilität und ihre wahrscheinliche Ursache in natürlichen Populationen des Erregers von Blattflecken (Bipolaris sorokiniana) an Weizen (Triticum aestivum L.) in Indien. Zeitschrift für Pflanzenkrankheiten und Pflanzenschutz / J. Plant Dis. Prot. 110, 27-35 (2003).

5. Saari, E. E. Leaf blight diseases and associated soil borne fungal pathogens of wheat in north \& south East Asia. In Helminthosporium Blights wheat Spot Blotch Tan Spot (eds. Duveiller, E. et al.) Mc Nab.37-51, CIMMYT, Mex. D.F. (1998).

6. Gupta, P. K. et al. Spot blotch disease of wheat: the current status of research on genetics and breeding. Plant Pathol. 67, 508-531 (2018).

7. van Ginkel, M. \& Rajaram, S. Breeding for resistance to spot blotch in wheat: Global perspective. In Proc. Int. Workshop. (eds Duveiller, E. et al.), Helminthosporium Blights of Wheat: Spot Blotch and Tan Spot, CIMMYT, Mexico, D. F. 162-170 (1998).

8. Sharma, S. et al. Natural variation in elicitation of defense-signaling associates to field resistance against the spot blotch disease in bread wheat (Triticum aestivum L.). Front. Plant Sci. 9, 636 (2018).

9. Duczek, L. J. \& Jones-Flory, L. L. Effect of timing of propiconazole application on foliar disease and yield of irrigated spring wheat in Saskatchewan from 1990 to 1992. Can. J. Plant Sci. 74, 205-207 (1994).

10. Mehta, Y. R., Riede, C. R., Campos, L. A. C. \& Kohli, M. M. Integrated management of major wheat diseases in Brazil: an example for the Southern Cone region of Latin America. Crop Prot. 11, 517-524 (1992).

11. Joshi, A. K. et al. Associations of environments in South Asia based on spot blotch disease of wheat caused by Cochliobolus sativus. Crop Sci. 47, 1071-1081 (2007).

12. Asseng, S., Foster, I. \& Turner, N. C. The impact of temperature variability on wheat yields. Glob. Chang. Biol. 17, 997-1012 (2011).

13. Rane, J. et al. Performance of yield and stability of advanced wheat genotypes under heat stress environments of the Indo-Gangetic plains. Crop Sci. 47, (2007).

14. Ortiz, R. et al. Climate change: Can wheat beat the heat?. Agric. Ecosyst. Environ. 126, 46-58 (2008).

15. Lobell, D. B. \& Field, C. B. Global scale climate-crop yield relationships and the impacts of recent warming Related content Global scale climate-crop yield relationships and the impacts of recent warming. Environ. Res. Lett 2, 14002-14009 (2007).

16 Lobell, D. B., Schlenker, W. \& Costa-Roberts, J. Climate trends and global crop production since 1980. Science 333, 616-620 (2011).

17. IPCC. The physical science basis. In Contribution of Working Group I to the Fourth Assessment Report of the Intergovernmental Panel on climate change (eds Solomon, S. et al.) (Cambridge Univ. Press, 2007).

18. Duveiller, E., Kandel, Y. R., Sharma, R. C. \& Shrestha, S. M. Epidemiology of foliar blights (spot blotch and tan spot) of wheat in the plains bordering the himalayas. Phytopathology 95, 248-256 (2005).

19. Rosyara, U., Subedi, S., Sharma, R. \& Duveiller, E. Spot blotch and terminal heat stress tolerance in south Asian spring wheat genotypes. Acta Agron. Hungarica 57, 425-435 (2009).

20. Chowdhury, A. K. et al. Spot blotch disease of wheat-a new thrust area for sustaining productivity. J. Wheat Res. 5, 1-11 (2013).

21. Hays, D. B., Do, J. H., Mason, R. E., Morgan, G. \& Finlayson, S. A. Heat stress induced ethylene production in developing wheat grains induces kernel abortion and increased maturation in a susceptible cultivar. Plant Sci. 172, 1113-1123 (2007).

22. Burgos, S., Stamp, P. \& Schmid, J. E. Agronomic and physiological study of cold and flooding tolerance of spelt (Triticum spelta L.) and wheat (Triticum aestivum L.). J. Agron. Crop Sci. 187, 195-202 (2001).

23. Hussain, S. et al. Heat stress in wheat and interdisciplinary approaches for yield maximization. In Plant-Environment Interaction 161-183 (Wiley, 2015). https://doi.org/10.1002/9781119081005.ch9

24. Babenko, L. M. et al. Triticum spelta: Origin, biological characteristics and perspectives for use in breeding and agriculture. Regul. Mech. Biosyst. 9, 250-257 (2018).

25. Duba, A., Goriewa-Duba, K., Wachowska, U., Głowacka, K. \& Wiwart, M. The associations between leaf morphology, phenylalanine ammonia lyase activity, reactive oxygen species, and fusarium resistance in selected species of wheat with different ploidy levels. Plants 8, 360 (2019).

26. Ni, Z. et al. Genetic improvement of heat tolerance in wheat: recent progress in understanding the underlying molecular mechanisms. Crop J. 6, 32-41 (2018).

27. Stone, P. J. \& Nicolas, M. E. Effect of timing of heat stress during grain filling on two wheat varieties differing in heat tolerance. II. Fractional protein accumulation. Aust. J. Plant Physiol. 23, 739-749 (1996).

28. Lobell, D. B., Sibley, A. \& Ivan Ortiz-Monasterio, J. Extreme heat effects on wheat senescence in India. Nat. Clim. Chang. 2, 186-189 (2012). 
29. Sharma, D. K., Andersen, S. B., Ottosen, C. O. \& Rosenqvist, E. Wheat cultivars selected for high Fv/Fm under heat stress maintain high photosynthesis, total chlorophyll, stomatal conductance, transpiration and dry matter. Physiol. Plant. 153, 284-298 (2015).

30. Ji, X. et al. Importance of pre-anthesis anther sink strength for maintenance of grain number during reproductive stage water stress in wheat. Plant, Cell Environ. 33, 926-942 (2010).

31. Sattar, A. et al. Terminal drought and heat stress alter physiological and biochemical attributes in flag leaf of bread wheat. PLoS ONE 15, e0232974 (2020).

32. Sharma, R. C. \& Duveiller, E. Effect of helminthosporium leaf blight on performance of timely and late-seeded wheat under optimal and stressed levels of soil fertility and moisture. Field Crop. Res. 89, 205-218 (2004).

33. Sharma, R. C., Duveiller, E. \& Ortiz-Ferrara, G. Progress and challenge towards reducing wheat spot blotch threat in the Eastern Gangetic Plains of South Asia: Is climate change already taking its toll?. Field Crop. Res. 103, 109-118 (2007).

34. Saxesena, R. R. et al. Pooling together spot blotch resistance, high yield with earliness in wheat for eastern Gangetic Plains of South Asia. Field Crop. Res. 214, 291-300 (2017).

35. Singh, P. K. et al. Resistance to spot blotch in two mapping populations of common wheat is controlled by multiple QTL of minor effects. Int. J. Mol. Sci. 19, 4054 (2018).

36. Zhu, Z. et al. Mapping resistance to spot blotch in a CIMMYT synthetic-derived bread wheat. Mol. Breed. 34, 1215-1228 (2014).

37. Duveiller, E. M. \& Sharma, R. C. Genetic improvement and crop management strategies to minimize yield losses in warm nontraditional wheat growing areas due to spot blotch pathogen Cochliobolus sativus. J. Phytopathol. 157, 521-534 (2009).

38. Mondal, S. et al. Earliness in wheat: a key to adaptation under terminal and continual high temperature stress in South Asia. Field Crop. Res. 151, 19-26 (2013).

39. Mondal, S. et al. Grain yield, adaptation and progress in breeding for early-maturing and heat-tolerant wheat lines in South Asia. Field Crop. Res. 192, 78-85 (2016).

40. Hedhly, A., Hormaza, J. I. \& Herrero, M. Global warming and sexual plant reproduction. Trends Plant Sci. 14, 30-36 (2009).

41. Saini, H. S. \& Aspinall, D. Abnormal sporogenesis in wheat (Triticum aestivum L.) induced by short periods of high temperature. Ann. Bot. 49, 835-846 (1982).

42. Shirdelmoghanloo, H. et al. A QTL on the short arm of wheat (Triticum aestivum L.) chromosome 3B affects the stability of grain weight in plants exposed to a brief heat shock early in grain filling. BMC Plant Biol. 16, 100 (2016).

43. Pradhan, G. P., Prasad, P. V. V., Fritz, A. K., Kirkham, M. B. \& Gill, B. S. Effects of drought and high temperature stress on synthetic hexaploid wheat. Funct. Plant Biol. 39, 190 (2012).

44. Weldearegay, D. F., Yan, F., Jiang, D. \& Liu, F. Independent and combined effects of soil warming and drought stress during anthesis on seed set and grain yield in two spring wheat varieties. J. Agron. Crop Sci. 198, 245-253 (2012).

45. Oshino, T. et al. Auxin depletion in barley plants under high-temperature conditions represses DNA proliferation in organelles and nuclei via transcriptional alterations. Plant, Cell Environ. 34, 284-290 (2011).

46. Anjum, F., Wahid, A., Javed, F. \& Arshad, M. Influence of foliar applied thiourea on flag leaf gas exchange and yield parameters of bread wheat (Triticum aestivum) cultivars under salinity and heat stresses. (2008).

47. Qaseem, M. F., Qureshi, R. \& Shaheen, H. Effects of pre-anthesis drought, heat and their combination on the growth, yield and physiology of diverse wheat (Triticum aestivum L.) genotypes varying in sensitivity to heat and drought stress. Sci. Rep. 9, 1-12 (2019).

48. Panse, G. \& Sukhatme, P. V. Statistical methods for agricultural workers / by V. - Details - Trove. https://trove.nla.gov.au/work/21381 741 (1985).

49. Joshi, A. K. \& Chand, R. Variation and inheritance of leaf angle, and its association with spot blotch (Bipolaris sorokiniana) severity in wheat (Triticum aestivum). Euphytica 124, 283-291 (2002).

50. Chand, R., Yadav, O. P., Bashyal, B. M., Prasad, L. C. \& Joshi, A. K. Technique for the maintenance of heterokayotic isolates of Bipolaris sorokiniana under ordinary conditions. Indian Phytopathol. 66, 61-65 (2013).

51. Chaurasia, S., Joshi, A. K., Dhari, R. \& Chand, R. Resistance to foliar blight of wheat: a search. Genet. Resour. Crop Evol. 46, 469-475 (1999).

52. Saari, E. E. \& Prescott, J. M. A scale for appraising the foliar intensity of wheat diseases. Plant Dis. Report. 59, 377-380 (1975).

53. Zadoks, J. C., Chang, T. T. \& Konzak, C. F. A decimal code for the growth stages of cereals. Weed Res. 14, 415-421 (1974).

54. Eyal, Z., Scharen, A. L., Prescott, J. M. \& van Ginkel, M. The Septoria Diseases of Wheat: Concepts and Methods of Disease Management Maarten van Ginkel. (CIMMYT, 1987).

55. Shaner, G. \& Finney, R. E. The effect of nitrogen fertilization on the expression of slow-mildewing resistance in knox wheat. Phytopathology 77, 1051 (1977).

56. Fernandez, G. C. J. Effective selection criteria for assessing plant stress tolerance. Adapt. food Crop. to Temp. water Stress (1992) https://doi.org/10.22001/WVC.72511

57. R core team. R: A language and environment for statistical computing. R Found. Stat. Comput. Vienna, Austria. www.R-proje ct.org/. (2019).

\section{Acknowledgements}

Vinod Kumar Mishra acknowledged Department of Biotechnology, New Delhi for financial assistance. Sandeep Sharma acknowledged Institute of Eminence, BHU for the allocation of seed money grant (6031).

\section{Author contributions}

A.K.P. carried out field experimentation, drafted the manuscript, and contributed to manuscript finalization; V.K.M. planned the experiment and contributed to the manuscript finalization; R.C. planned the experiment; S.N. carried out field experiments; N.B. carried out statistical analysis; S.S. contributed to manuscript preparation and finalization; J.S. developed the experimental population; A.K.J. planned the experiment, contributed to manuscript preparation and finalization.

\section{Competing interests}

The authors declare no competing interests.

\section{Additional information}

Correspondence and requests for materials should be addressed to V.K.M.

Reprints and permissions information is available at www.nature.com/reprints.

Publisher's note Springer Nature remains neutral with regard to jurisdictional claims in published maps and institutional affiliations. 
(c) (i) Open Access This article is licensed under a Creative Commons Attribution 4.0 International cc) License, which permits use, sharing, adaptation, distribution and reproduction in any medium or format, as long as you give appropriate credit to the original author(s) and the source, provide a link to the Creative Commons licence, and indicate if changes were made. The images or other third party material in this article are included in the article's Creative Commons licence, unless indicated otherwise in a credit line to the material. If material is not included in the article's Creative Commons licence and your intended use is not permitted by statutory regulation or exceeds the permitted use, you will need to obtain permission directly from the copyright holder. To view a copy of this licence, visit http://creativecommons.org/licenses/by/4.0/.

(C) The Author(s) 2021 